\title{
Determination of the volatile and polyphenol constituents and the antimicrobial, antioxidant, and tyrosinase inhibitory activities of the bioactive compounds from the by-product of Rosa rugosa Thunb. var. plena Regal tea
}

Guixing Ren ${ }^{1,4^{*}+}$, Peng Xue ${ }^{2,4^{\dagger}}$, Xiaoyan $\operatorname{Sun}^{4}$ and Gang Zhao ${ }^{3 *}$

\begin{abstract}
Background: The phytochemical constituents and biological activities of Rosa rugosa Thunb. var. plena Regal flower cell sap (RFCS) were investigated.

Methods: Volatile constituent, such as linalool, phenylethyl alcohol, citronellol, a-bisabolol, were identified by GCMS. The contents of hyperoside, kaempferol-3-O-rutinosid, rutin, and luteolin as well as the total flavonoid content in RFCS were determined by HPLC and HPLC-MS. The total polyphenol content was evaluated by the Folin-Ciocalteu colorimetric method. The antioxidant activities of RFCS and the standards were evaluated by DPPH and ABTS radical scavenging assays. The tyrosinase inhibitory activities of the rose samples and standard substance were determined by a spectrophotometric method. The antimicrobial effects of RFCS were evaluated in terms of minimum inhibitory concentrations (MICS) and minimum bactericidal concentrations (MBCs) or minimum Fungicidal concentrations (MFCs).

Results: The rose fraction exhibited a high content of biologically active ingredients. The total content of volatile compounds in RFCS was approximately $48.21 \pm 2.76 \mathrm{ng} / \mathrm{mL}$. The total phenolic acid content and total flavonoid content were $0.31 \pm 0.01 \mathrm{mg} / \mathrm{mL}$ and $0.43 \pm 0.01 \mathrm{mg} / \mathrm{mL}$, respectively. Its IC $C_{50}$ value in the $D P P H$ assay was $1120 \pm 42 \mu \mathrm{g} / \mathrm{mL}$, and its $I C_{50}$ value for ABTS radical scavenging activity was $1430 \pm 42 \mu \mathrm{g} / \mathrm{mL}$.RFCS strongly inhibited L-tyrosine oxidation with an $I_{50}$ value of $570 \pm 21 \mu \mathrm{g} / \mathrm{mL}$. Every compound identified in RFCS exhibited broad-spectrum antimicrobial activity. F. nucleatum was most susceptible to RFCS with an MIC of $64 \mu \mathrm{g} / \mathrm{mL}$ and MBC of $250 \mu \mathrm{g} / \mathrm{mL}$.
\end{abstract}

Conclusions: Due to its rose-like aroma, phenylethyl alcohol may be combined with linalool for use as a natural skin-whitening agent and skin care additive in the and pharmaceutical industries.

Keywords: RFCS, Phytochemical constituents, Antioxidant, Antimicrobial, Tyrosinase inhibitory activities

* Correspondence: renguixing@cdu.edu.cn; zhaogang@cdu.edu.cn

${ }^{\dagger}$ Guixing Ren and Peng Xue contributed equally to this work.

${ }^{1}$ College of Pharmacy and Biological Engineering, Chengdu University,

Chengdu 610000, People's Republic of China

${ }^{3}$ Key Laboratory of Coarse Cereal Processing, Ministry of Agriculture, No.2025

Chengluo Road, Longquanyi District, Chengdu 610106, People's Republic of

China

Full list of author information is available at the end of the article

(c) The Author(s). 2018 Open Access This article is distributed under the terms of the Creative Commons Attribution 4.0 International License (http://creativecommons.org/licenses/by/4.0/), which permits unrestricted use, distribution, and reproduction in any medium, provided you give appropriate credit to the original author(s) and the source, provide a link to the Creative Commons license, and indicate if changes were made. The Creative Commons Public Domain Dedication waiver (http://creativecommons.org/publicdomain/zero/1.0/) applies to the data made available in this article, unless otherwise stated. 


\section{Background}

The flower of Rosa rugosa Thunb. var. plena Regal is not only used in perfume production but has also been used as a health food and medicine in Asian countries for thousands of years. Additionally, roses contain active materials, such as essential oils, polyphenols, flavonoids and anthocyanin, which are known for their antimicrobial, anti-inflammatory, hypoglycemic, and antioxidant activities [1-4]. Roses can be consumed in many forms, such as rose teas, rose cookies, and rose oils. The production of rose tea or dried flower petals via low-temperature drying of rose flowers (Rosa rugosa cv. Plena) yields a condensate called "rose flower cell sap" (RFCS). The disposal of RFCS represents a great waste of resources due to its high content of polyphenols and rose essential oil, which has very high biological activity. In addition, environmental pollution may be caused by the improper disposal of RFCS because it is difficult to decompose. In addition, essential oils and polyphenols are active ingredients in the pharmaceutical, cosmetic, and food industries. The drying of $1 \mathrm{~kg}$ of raw rose petals or flower bud material can produce approximately $0.2 \mathrm{~L}$ of condensate. Approximately $40,000 \mathrm{~kg}$ of rose flower buds and $20,000 \mathrm{~kg}$ of petals are used per cycle of industrial microwave-drying in Pingyin alone. To date, no studies have reported a suitable method for the disposal of RFCS and the bioactive compounds contained therein.

Rose oil distillation wastewater (RODW) is another by-product of the steam distillation of dried rose flowers to product rose oil. In previous studies, RODW has been concentrated to generate a polyphenol-enriched residue containing non-volatile phenolic compounds [5]. Moreover, the polyphenol fraction of RODW can strongly inhibit mushroom tyrosinase ( $\mathrm{IC}_{50}$ value of $0.41 \mu \mathrm{g} / \mathrm{mL}$ ) [6]. Thus, the polyphenols in RODW may be used as a bioactive substance to relieve hyperpigmentation.

Food-related pathogenic bacteria cause foodborne illnesses in millions of people and even hundreds of deaths every year in the USA alone, and the associated cost total approximately $\$ 2.4$ billion [7]. Thus, the increasing demand for healthy, non-toxic, and effective antimicrobial agents has inspired research on multifunctional, naturally produced food additives. Although rose oil primarily contains essential oils known for their antimicrobial activities [8], the antimicrobial effects of RFCS have not been investigated.

The phenolic compounds and volatile substances in flowers have strong biological activities such as antioxidant and tyrosinase inhibitory effects [9]. The development of additional methods for inhibiting tyrosinase activity is an active area of research in the functional cosmetics and food industries due to tyrosinase's whitening effect and ability to control browning $[10,11]$. Antioxidants may lower the risks of health concerns such as cancer, aging, and atherosclerosis by reducing the level of reactive oxygen species (ROS) [12]. Some antioxidants, such as ascorbic acid, also have been reported to have whitening effects [11].

In our preliminary test, antimicrobial, antioxidant, and tyrosinase inhibitory activities of RODW from Rosa rugosa Thunb. var. plena Regal were evaluated [13]. However, there are no reports in the literature investigating the phytochemical composition and biological activities of RFCS from Rosa rugosa cv. Plena. In this study, (1) contents of the total phenolics, flavonoids, total solid and volatile contents were investigated; (2) the antibacterial (six strains) and anti fungal (one strain) activity, antioxidant, and tyrosinase inhibitory activities of each active compound and RFCS were examined. Our results will help to improve the value of roses in the fields of medicinal and cosmetic products [13-16].

\section{Methods \\ Chemicals}

Phenylethyl alcohol, $\alpha$-bisabolol, $\alpha$-terpineol, citronellol, miconazole nitrate, hydrochloride tetracycline, menthol and camphor were purchased from J\&K Scientific Ltd. (Beijing). Kojic acid, hyperoside, quercetin, gallic acid, kaempferol-3-O-acetylglucosylrhamnoside and kaempferol-3-O-glucoside were purchased from Sigma (Shanghai, China). Anaerobic blood agar base medium (CDC), actinomycete broth medium (GAM broth), brain heart infusion (BHI) broth, and nutrient agar were obtained from Suolaibao Biotech Co., Ltd. (Beijing, China). The remaining chemicals were analytical or chromatographic grade.

\section{Sample preparation}

RFCS of Rosa rugosa Thunb. var. plena Regal was obtained from Fragrant Rose Biological Technology Co., LTD in Pingyin. The samples were filtered through a $0.42 \mu \mathrm{m}$ microfiltration membrane prior to analyses. The total solid content of RFCS was evaluated by freeze-drying. The identification of Rosa rugosa Thunb. var. plena Regal was identificated by senior agronomist Guo and confirmed in voucher sample (Ser. No. 0712) deposited at Herbarium, Pingyin Institute of Rose Sciences.

\section{HPLC analyses}

The concentration of polyphenol constituents in the extract was determined by HPLC and UV analyses. The HPLC apparatus was an LC-20A HPLC system (Shimadzu Corporation, Kyoto, Japan), and it was equipped with an Ultrasphere $5 \mathrm{C}_{18}$ column $(4.6 \mathrm{~mm} \times 250 \mathrm{~mm}$, Ultrasphere Co., Ltd., Berkshire, UK). The mobile phase was a gradient elution of water (A) and acetonitrile (B) and was programmed as follows: starting with $10 \%$ B for $10 \mathrm{~min}$, $10-25 \%$ B between 15 and $20 \mathrm{~min}, 25-30 \%$ B between 
20 and $25 \mathrm{~min}, 30-60 \%$ B between 25 and $50 \mathrm{~min}, 60-10 \%$ $\mathrm{B}$ between 50 and $51 \mathrm{~min}$, and 10\% B between 51 and 55 min. The flow rate of the mobile phase was maintained at $1 \mathrm{~mL} / \mathrm{min}$, the detector wavelength was set at $350 \mathrm{~nm}$, the column oven was set at $25^{\circ} \mathrm{C}$, and the sample injection volume was $10 \mu \mathrm{L}$.

\section{HPLC-ESI-MS conditions}

The electrospray ionization (ESI) mass spectrometry (MS) data were recorded on an Agilent-LC-1100 instrument (Agilent, USA). The HPLC conditions for the HPLC-ESI-MS analysis were as described above. The ESI parameters were as follows: the collision gas $\left(\mathrm{N}_{2}\right)$ flow rate was maintained at $10 \mathrm{~mL} / \mathrm{min}$, the column oven was $25^{\circ} \mathrm{C}$, data were acquired in negative ionmode $[\mathrm{M}-\mathrm{H}]^{-}$, scans were conducted over $\mathrm{m} / \mathrm{z} 50-2000$, the spray voltage was $4.5 \mathrm{kV}$, the capillary voltage was $10 \mathrm{~V}$, and the capillary temperature was $250{ }^{\circ} \mathrm{C}$. The components in the sample were identified based on their mass spectral data and retention time.

\section{GC/MS analysis}

The volatile constituents in RFCS were determined by a Shimadzu GC/MS model QP2010 Ultra system equipped with an Rtx-5MS $(30 \mathrm{~m} \times 0.25 \mathrm{~mm}$, film thickness $0.25 \mu \mathrm{m}$ ) capillary column. The oven program was as follows: starting at $60^{\circ} \mathrm{C}$, heating to $120^{\circ} \mathrm{C}$ at a rate of $1.7^{\circ}$ $\mathrm{C} / \mathrm{min}$, heating to $200^{\circ} \mathrm{C}$ at $2.5^{\circ} \mathrm{C} / \mathrm{min}$, heating to $260{ }^{\circ} \mathrm{C}$ at a rate of $8{ }^{\circ} \mathrm{C} / \mathrm{min}$, and finally holding at $260^{\circ} \mathrm{C}$ for 2 min. Helium was used as the carrier gas, and the flow rate was $1.0 \mathrm{~mL} / \mathrm{min}$. The injector and detector temperatures were held at $250{ }^{\circ} \mathrm{C}$ and $280^{\circ} \mathrm{C}$, respectively. A split injection was conducted in splitless mode. The ion source temperature was $250{ }^{\circ} \mathrm{C}$ and its ionization energy was $70 \mathrm{eV}$. The mass range was $35-500 \mathrm{Da}$. The components in the sample were identified based on their mass spectral data and retention time.

\section{Preparation of standard curves}

Solutions of phenylethyl alcohol (2.23 mg), $\alpha$-bisabolol (2.1 mg), $\alpha$-terpineol (5.23 mg), citronellol (1.52 mg), menthol $(1.32 \mathrm{mg})$, and camphor were separately prepared in $1 \mathrm{~mL}$ of acetonitrile. Next, the stock solutions were diluted by factors of ten thousand to one billion with ethyl acetate, and $1 \mu \mathrm{L}$ of each sample was analyzed by GS/MS. Solutions of kojic acid (1.12 mg), hyperoside $(1.07 \mathrm{mg})$, quercetin $(1.07 \mathrm{mg})$, gallic acid $(1.29 \mathrm{mg})$, and kaempferol-3-O-acetylglucosylrhamnoside $(1.15 \mathrm{mg})$ were separately prepared in $1 \mathrm{~mL}$ of methyl alcohol. The stock solutions were diluted by factors of 2 with methyl alcohol, and $10 \mu \mathrm{L}$ of each solution was analyzed by HPLC. Each concentration of working solution was analyzed in three times. The calibration curves were plotted as the peak areas against the concentration of each standard. The content of the reference substance in each sample was calculated using the calibration curves.

\section{Determination of total phenolics, flavonoids and total solid content}

The total phenolic contents of the RFCS were evaluated by the Folin-Ciocalteu colorimetric method [17]. The total content of phenolic substance was determined by comparison to a standard curve of gallic acid. The total flavonoid contents of the RFCS samples were evaluated by HPLC, which provided the total amount of all tested flavonoid compounds. A 10-mL sample of RFCS was freeze-dried to determine the total solid content. Every determination was carried out in triplicate.

\section{Antioxidant properties \\ $D P P H$ radical scavenging activity}

The antioxidant activity of RFCS and the standards were evaluated by $\mathrm{DPPH}$ radical scavenging activity using a slightly modified version of a previously reported method [18]. Briefly, $10 \mu \mathrm{L}$ aliquots of the rose samples $(1000 \mu \mathrm{g} / \mathrm{mL}$ to $62.5 \mu \mathrm{g} / \mathrm{mL})$ were mixed with $190 \mu \mathrm{L}$ of $50 \%$ ethanol containing $0.4 \mathrm{mM} \mathrm{DPPH}$ and incubated in the dark for $30 \mathrm{~min}$. Aliquots $(100 \mu \mathrm{L})$ of the supernatants were transferred into a 96-well microplate, and the absorbance of each was recorded at $517 \mathrm{~nm}$ using a Spectramax Plus384 UV-Vis spectrophotometer (Molecular Devices, Sunnyvale, California, USA). Ascorbic acid $(1000 \mu \mathrm{g} / \mathrm{mL}$ to $0.05 \mu \mathrm{g} / \mathrm{mL})$ was used as a positive control, and DPPH solution without sample was used as the negative control. The $\mathrm{IC}_{50}$ values, which represent the concentrations of rose samples and standard substance at which $50 \%$ of the DPPH radical was inhibited, were determined. The tests were performed in triplicate, and the percentage of DPPH scavenging was calculated using the following equation.

$$
\begin{aligned}
& \text { Inhibition }(\%)=\left\{\left(\mathrm{H}_{0}-\mathrm{H}\right) / \mathrm{H}_{0}\right\} \times 100 \\
& \mathrm{H}: \text { Absorbance of RFCS and the standards; } \\
& \mathrm{H}_{0}: \text { Absorbance of the blank }
\end{aligned}
$$

\section{Determination of ABTS radical scavenging}

The ABTS assay of RFCS was performed according to a modified version of a previously reported method [19]. Briefly, the stock solutions were generated by mixing equal quantities of $7.4 \mathrm{mM} \mathrm{ABTS}^{\bullet+}$ solution and $2.6 \mathrm{mM}$ potassium persulfate solution, and the mixture was incubated at room temperature for $12 \mathrm{~h}$ in the dark. Then, the solution was equilibrated with $1 \mathrm{~mL}$ of ABTS $^{\bullet+}$ solution with $50 \%$ ethanol serving as a positive control. The absorbance of the solution at $734 \mathrm{~nm}$ was $1.17 \pm 0.02$ units. Aliquots $(10 \mu \mathrm{L})$ of the rose samples 
$(1000 \mu \mathrm{g} / \mathrm{mL}$ to $62.5 \mu \mathrm{g} / \mathrm{mL})$ were mixed with $1.0 \mathrm{~mL}$ of the diluted $\mathrm{ABTS}^{*+}$ solution. The mixture was mixed vigorously and incubated at $30^{\circ} \mathrm{C}$ for $30 \mathrm{~min}$. The absorbance was then measured at $520 \mathrm{~nm}$ with an excitation wavelength of $734 \mathrm{~nm}$ using the spectrophotometer. The positive standard was Trolox $(2000 \mu \mathrm{g} / \mathrm{mL}$ to $0.05 \mu \mathrm{g} / \mathrm{mL})$.

Inhibition $(\%)=\{($ Absorbance of blank - Absorbance of sample $)$ /Absorbance of blank $\} \times 100$

\section{Determination of the Tyrosinase inhibitory activity}

The tyrosinase inhibitory activities of the rose samples and standard substance were determined by a spectrophotometric method [17]. First, $300 \mu \mathrm{L}$ aliquots of different concentrations $(1000 \mu \mathrm{g} / \mathrm{mL}$ to $62.5 \mu \mathrm{g} / \mathrm{mL})$ of each sample were diluted with $700 \mu \mathrm{L}$ of $0.175 \mathrm{M}$ sodium phosphate buffer (pH 6.8), then $1.0 \mathrm{~mL}$ of $10 \mathrm{mM}$ DOPA solution and $1.0 \mathrm{~mL}$ of mushroom tyrosinase $(220$ units $/ \mathrm{mL}$ ) were added. Ethanol $(300 \mu \mathrm{L}, 50 \%)$ and kojic acid $(2000 \mu \mathrm{g} / \mathrm{mL}$ to $0.1 \mu \mathrm{g} / \mathrm{mL}$ ) were used as the blank reference and positive standard, respectively. The reaction mixture was vortexed and maintained at $37^{\circ} \mathrm{C}$ for $15 \mathrm{~min}$, and then the absorption maximum of dopachrome (set at $479 \mathrm{~nm}$ ) was measured using a microplate reader (Molecular Devices, Sunnyvale, California, USA). The tests were performed in triplicate, and the value of tyrosinase inhibition activity was calculated as described above.

\section{Antimicrobial properties}

\section{Antibacterial and antifungal assays}

The antimicrobial activity was measured by the method described by Xue [20]. All standard strains were obtained from the Guangdong Microbiology Culture Center (Guangzhou, China). Listeria ivanovii (ATCC 19119) was cultured in BHI, Salmonella enteritidis enteritidis (ATCC 14028) Staphylococcus aureus (ATCC 25923) and Escherichia coli (ATCC 25922) were cultured in nutrient agar (NA) for $24 \mathrm{~h}$ and at $37^{\circ} \mathrm{C}$. candida albicans (ATCC 10231) was cultured in PHB at $37^{\circ} \mathrm{C}$ for $24 \mathrm{~h}$. Propionibacterium acnes (ATCC 6919) and Fusobacterium nucleatum (ATCC 10953) were cultured in CDC agar at $37^{\circ} \mathrm{C}$ for $48 \mathrm{~h}$ in a YQX-II anaerobic incubator (Shanghai, China). The final cell counts in $1 \mathrm{~mL}$ of broth were approximately $10^{6}$ colony-forming units $(\mathrm{CFU} / \mathrm{mL})$. A $10 \mathrm{mg} / \mathrm{mL}$ solution of miconazole nitrate and hydrochloride tetracycline in water was used as a positive control against fungi and bacteria, respectly.

\section{Determination of minimum inhibitory concentration (MIC) and minimum bactericidal concentration $(M B C)$ or minimum fungicidal concentration (MFC)}

The MIC and MBC or MFC values were determined as described previously by Xue. Briefly, $100 \mu \mathrm{L}$ dilutions (approximately 100,000 CFU/mL) of Staphylococcus aureus, Escherichia coli, Salmonella enteritidis enteritidis, Fusobacterium nucleatum, and Candida albicans in nutrient broth and Listeria ivanovii and Propionibacterium acnes in GMA broth were inoculated into microtiter plates. Then, $100 \mu \mathrm{L}$ aliquots of the solutions of the test compound were added after a two-fold serial dilution with nutrient broth (from $2 \mathrm{mg} / \mathrm{mL}$ to $3 \mu \mathrm{g} / \mathrm{mL}$ ). Broths with 5\% $(v / v)$ DMSO were used as controls. The petri dishes were incubated at $37^{\circ} \mathrm{C}$ for $24 \mathrm{~h}$ with the exception of Propionibacterium acnes and Fusobacterium nucleatum, which were incubated at $37^{\circ} \mathrm{C}$ for $48 \mathrm{~h}$. The MIC was recorded as the lowest concentration of sample showing no detectable growth. To determine the MBC or MFC values for no bacterial or fungus growth, $10 \mu \mathrm{L}$ of sub-inhibitory concentrations of the test compounds were incubated on CDC or GMA agar plates for 24 or $48 \mathrm{~h}$. Every determination was carried out in triplicate.

\section{Date analysis}

Data are presented as the mean of three replicates \pm standard deviation. One-way ANOVA with Duncan's multiple range test was used to analyze the results with SPSS 13.0 and Sigma Plot 10.0, respectively, using a computer (Lenovo, Yangtian B 41) equipped with the Win 7 operating system. A $p$ value of $<0.05$ was determined to be statistically significant.

\section{Results and discussion}

\section{The contents of volatile substance}

Since the RFCS samples had a specific rose fragrance, we analyzed and compared the volatile components of its ethyl acetate extract. The contents of the volatile components of the ethyl acetate extract of RFCS were determined by GC/MS and analyzed by comparison to four standard curves, and the results are expressed as $\mathrm{ng} / \mathrm{mL}$.

Six principal components were simultaneously identified according to their standard retention times and MS ion fragments. The GC chromatograms of the reference substance in RFCS are shown in Fig. 1. The content of each element in every sample is presented in Table 1. As shown in Fig. 1, six compounds were successfully separated under the gradient temperature program. The total content of volatile compounds in RFCS was approximately $48.21 \pm 2.76 \mathrm{ng} / \mathrm{mL}$, and six major kinds of volatile compounds, including phenylethyl alcohol $(40.48 \pm 2.24 \mathrm{ng} / \mathrm{mL})$, citronellol $(7.83 \pm 0.77 \mathrm{ng} / \mathrm{mL})$, $\alpha$-bisabolol $(0.08 \pm 0.01 \mathrm{ng} / \mathrm{mL})$ and phenylethyl acetate $(11.20 \pm 0.89 \mathrm{ng} / \mathrm{mL})$ were identified (two peaks have not been identified and the content of linalool is rare). In previous studies on the volatile compounds in RODW, GC-MS, more specifically HS-SPME/GC/MS, techniques have been widely utilized [13, 21-24]. In 

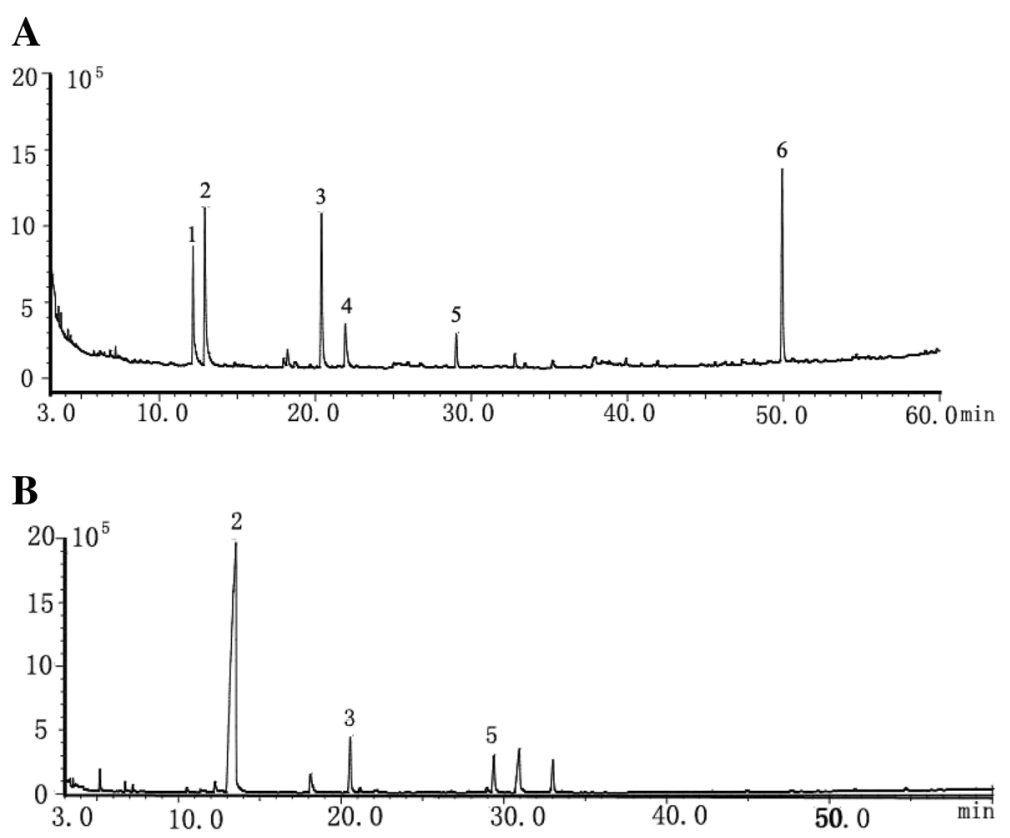

Fig. 1 a Total ion chromatogram of volatile compounds in ethyl acetate from standard substance (a), and rose flowers cell sap (b). RFCS: rose flower cell sap. Identification of peaks. 1, linalool; 2, phenylethyl alcohol; 3, citronellol; 4, ester phenylethyl acetate; 5, citronellol acetate; 6, a-bisabolol

contrast to these previous studies, our study reports the absolute contents of the components. Although there was a broad range of volatile compounds, there were no differences in the dominant components. The major volatile compounds in RFCS were monoterpene alcohols (citronellol, linalool, and phenylethyl alcohol, which is specific to small roses). The types of dominant components in RFCS are similar to those of RODW, but there is a significant difference in the contents of the components [13]. One possible reason for these differences is that most of the volatile components were lost in the rose tea drying process.

\section{Total phenolic, flavonoid and soild contents}

The flavonoids, their retention times, and the calibration curves of standard compounds in RFCS, as determined

Table 1 Analytical characteristics of volatile substances in rose waste. $(\mathrm{ng} / \mathrm{mL})$

\begin{tabular}{lllll}
\hline Compound & RT & Formula structure & Weight & RFCS \\
\hline Linalool & 12.163 & $\mathrm{C}_{10} \mathrm{H}_{18} \mathrm{O}$ & 154.25 & n.d \\
Phenylethyl alcohol & 12.921 & $\mathrm{C}_{8} \mathrm{H}_{10} \mathrm{O}$ & 122.16 & $40.48 \pm 2.24$ \\
Citronellol & 20.393 & $\mathrm{C}_{10} \mathrm{H}_{20} \mathrm{O}$ & 156.27 & $7.83 \pm 0.77$ \\
Phenylethyl acetate & 21.923 & $\mathrm{C}_{10} \mathrm{H}_{12} \mathrm{O}_{2}$ & 164.2 & $11.20 \pm 0.89$ \\
Citronellol acetate & 29.029 & $\mathrm{C}_{12} \mathrm{H}_{22} \mathrm{O}_{2}$ & 198.3 & n.d \\
a-bisabolol & 49.909 & $\mathrm{C}_{15} \mathrm{H}_{26} \mathrm{O}$ & 222.36 & $0.08 \pm 0.01$ \\
Total content & & & & $48.21 \pm 2.76$ \\
\hline
\end{tabular}

nd not detected; Data are expressed as mean \pm standard deviation of triplicate samples; $R F C S$ rose flower cell sap using HPLC, are showen in Fig. 2. Four compounds were successfully separated under the gradient temperature program, as showen in Fig. 2. The linearity of calibration curves and regression coefficients of flavonoids were demonstrated in Table 2. It was found that the reference compounds showed good linearity $\left(R^{2} \geq 0.997\right)$. RFCS was found to contain three main components, namely, hyperoside $(0.18 \pm 0.01 \mathrm{mg} / \mathrm{mL})$, kaempferol-3-O-rutinosid $(0.12 \pm 0.01 \mathrm{mg} / \mathrm{mL})$, and rutin $(0.23 \pm 0.01 \mathrm{mg} / \mathrm{mL})$. The total phenolic content and total flavonoid content were $0.31 \pm 0.01 \mathrm{mg} / \mathrm{mL}$ and $0.43 \pm 0.01 \mathrm{mg} / \mathrm{mL}$, respectively. The total solid content in RFCS was $1.45 \pm 0.04 \mathrm{mg} / \mathrm{mL}$.

Previous studies have reported that the dominant phenolic and flavonoid compounds in rose rugosa tea were gallic acid, catechin, epicatechin, and quercetin and the total polyphenol content and flavonoid content in the Rosa rugosa tea polyphenol extract were $875.2 \mathrm{mg} / \mathrm{g}$ and $610.3 \mathrm{mg} / \mathrm{g}$, respectively [1]. In addition, rutin, multiflorin B, hyperoside, kaepferol, and ellagic acid were also found in the resin fractions of RODW [6]. Furthermore, unlike previous studies, although our study used HPLC-MS to determine the phenol and flavonoid compounds in RODW, only one of the dominant compounds, kaempferol-3-O-rutinosid, was found in this study and in previous studies $[6,13]$. Neither of the phenol compounds was detected in RFCS by HPLC primarily because the concentrations of phenols and flavonoids in RFCS are very low, and thus they are undetectable by HPLC. Those solids in RFCS were mixture of small molecules. 
A

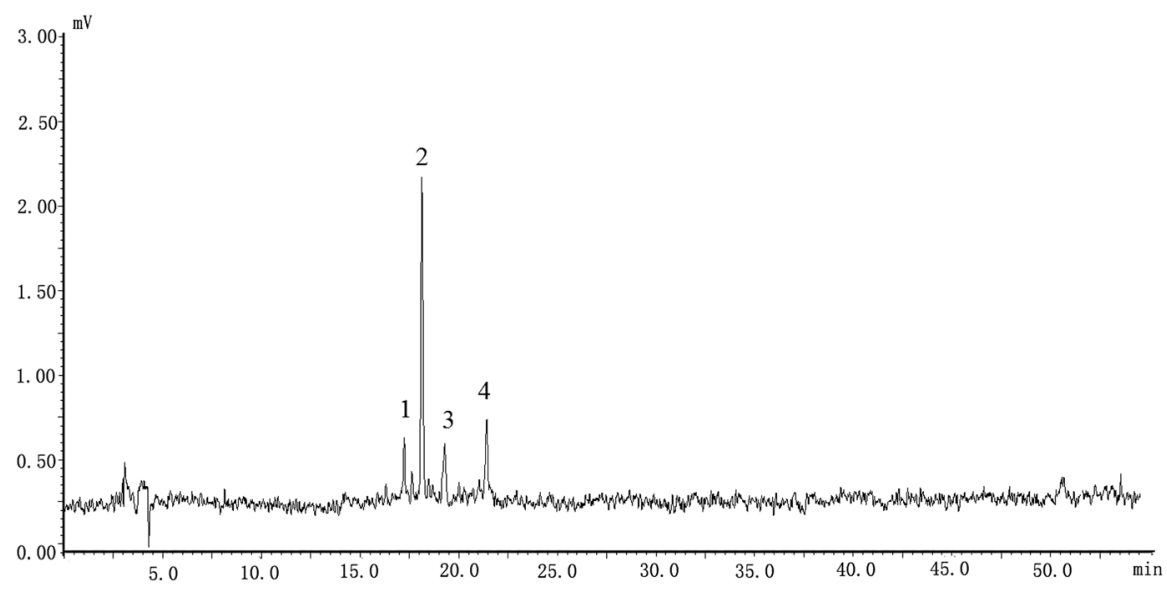

B

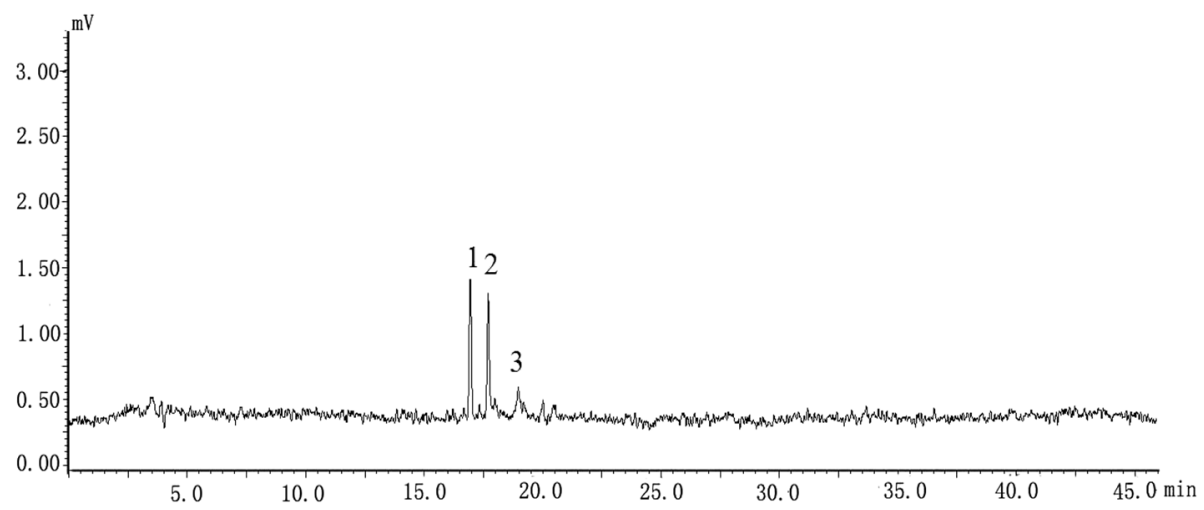

Fig. 2 HPLC chromatogram of standard substanceb (a), and rose flower cell sap (b). RFCS: rose flowers cell sap. Identification of peaks: 1, hyperoside; 2, kaempferol-3-O-rutinoside; 3, rutin; 4, luteolin

\section{Antioxidant capacity}

Table 3 presents the DPPH $\mathrm{IC}_{50}$ values of $\mathrm{RFCS}$ and the standard compounds. The flavonoids with $\mathrm{IC}_{50}$ values $<1 \mu \mathrm{g} / \mathrm{mL}$, including hyperoside $\left(\mathrm{IC}_{50}\right.$ value of $0.695 \pm 0.021 \mu \mathrm{g} / \mathrm{mL})$, kaempferol-3-O-rutinoside $\left(\mathrm{IC}_{50}\right.$ value of $0.808 \pm 0.024 \mu \mathrm{g} / \mathrm{mL})$, rutin $\left(\mathrm{IC}_{50}\right.$ value of $0.715 \pm 0.017 \mu \mathrm{g} / \mathrm{mL}$ ), and luteolin $\left(\mathrm{IC}_{50}\right.$ value of 0.507 $\pm 0.015 \mu \mathrm{g} / \mathrm{mL})$, showed stronger DPPH radical scavenging activities than RFCS ( $\mathrm{IC}_{50}$ value of $1120 \pm$
$42 \mu \mathrm{g} / \mathrm{mL})$. Single volatile compounds, such as linalool, phenylethyl alcohol, citronellol, and $\alpha$-bisabolol, showed weak radical scavenging activity with $\mathrm{IC}_{50}$ values of $>10,000 \mu \mathrm{g} / \mathrm{mL}$. In previous reports, the antioxidant activities of various natural products, including those from rose, have been attributed to the contents of phenolic compounds $[25,26]$. The ABTS radical assay is also used to evaluate the radical scavenging activity of hydrogen-donating and chain-breaking antioxidants in

Table 2 Analytical characteristics of compounds in rose waste. $(\mathrm{mg} / \mathrm{mL})$

\begin{tabular}{|c|c|c|c|c|c|}
\hline Peak & Ginsenoside & Retention time & Calibration curve & $R^{2}$ & RFCS \\
\hline 1 & hyperoside & 16.981 & $y=14,955 x-5214$ & 0.9989 & $0.18 \pm 0.01$ \\
\hline 2 & kaempferol-3-O-rutinoside & 17.737 & $y=7102 x+3256$ & 0.9984 & $0.12 \pm 0.01$ \\
\hline 3 & rutin & 19.01 & $y=41,285 x-43,792$ & 0.9979 & $0.23 \pm 0.01$ \\
\hline \multirow[t]{4}{*}{4} & luteolin & 22.01 & $y=31,527 x-5241$ & 0.9991 & n.d \\
\hline & total phenolic content & & & & $0.31 \pm 0.01$ \\
\hline & total flavonoid content & & & & $0.43 \pm 0.01$ \\
\hline & total solid content & & & & $1.45 \pm 0.04$ \\
\hline
\end{tabular}

nd not detected; Data are expressed as mean \pm standard deviation of triplicate samples; RFCS rose flower cell sap 
Table 3 Total solid content and $I C_{50}$ values of single compounds in rose products. $(\mu \mathrm{g} / \mathrm{mL})$

\begin{tabular}{llll}
\hline & DPPH radicalscavenging activity & Tyrosinase inhibition & ABTS radicalscavenging activity \\
\hline RFCS & $1120 \pm 42 \mathrm{~b}$ & $570 \pm 21 \mathrm{ab}$ & $1430 \pm 49 \mathrm{~b}$ \\
Linalool & $>10,000 \mathrm{a}$ & $730 \pm 44 \mathrm{a}$ & $>10,000 \mathrm{a}$ \\
Phenylethyl alcohol & $>10,000 \mathrm{a}$ & $315 \pm 13 \mathrm{~b}$ & $>10,000 \mathrm{a}$ \\
Citronellol & $>10000 \mathrm{a}$ & $825 \pm 31 \mathrm{a}$ & $>10,000 \mathrm{a}$ \\
a-bisabolol & $>10,000 \mathrm{a}$ & $635 \pm 22 \mathrm{a}$ & $>10,000 \mathrm{a}$ \\
Hyperoside & $0.695 \pm 0.021 \mathrm{c}$ & $0.762 \pm 0.018 \mathrm{~d}$ & $0.526 \pm 0.014 \mathrm{c}$ \\
Kaempferol-3-O-Rutinoside & $0.808 \pm 0.024 \mathrm{c}$ & $0.908 \pm 0.021 \mathrm{~d}$ & $0.719 \pm 0.016 \mathrm{c}$ \\
Rutin & $0.715 \pm 0.017 \mathrm{c}$ & $0.856 \pm 0.014 \mathrm{~d}$ & $0.621 \pm 0.024 \mathrm{c}$ \\
Luteolin & $0.507 \pm 0.015 \mathrm{c}$ & $0.613 \pm 0.016 \mathrm{~d}$ & $0.436 \pm 0.026 \mathrm{c}$ \\
Positive control & $0.449 \pm 0.013 \mathrm{c}$ & $80 \pm 17 \mathrm{c}$ & $0.324 \pm 0.019 \mathrm{c}$ \\
\hline
\end{tabular}

Data are expressed as mean \pm standard deviation of triplicate samples; RFCS rose flower cell sap

Values in each column followed by different letters are significantly different $(P<0.01)$

many natural products $[27,28]$. As shown in Table. 3, the ABTS radical scavenging activities of single compounds and RFCS are expressed as $\mu \mathrm{g} / \mathrm{mL}$. Consistent with previous works, flavonoids exhibited significantly higher antiradical activities and antioxidant capacities than volatile compounds $[8,13]$. In the present study, the results of ABTS scavenging were similar to those of DPPH; flavonoid compounds with $\mathrm{IC}_{50}$ values $<1 \mu \mathrm{g} / \mathrm{mL}$, including hyperoside $\left(\mathrm{IC}_{50}\right.$ value of $\left.0.526 \pm 0.014 \mu \mathrm{g} / \mathrm{mL}\right)$, kaempferol-3-O-rutinoside $\left(\mathrm{IC}_{50}\right.$ value of $0.719 \pm$ $0.016 \mu \mathrm{g} / \mathrm{mL}$ ), rutin $\left(\mathrm{IC}_{50}\right.$ value of $\left.0.621 \pm 0.024 \mu \mathrm{g} / \mathrm{mL}\right)$, and luteolin $\left(\mathrm{IC}_{50}\right.$ value of $\left.0.436 \pm 0.026 \mu \mathrm{g} / \mathrm{mL}\right)$, showed stronger ABTS radical scavenging activities than RFCS ( $\mathrm{IC}_{50}$ value of $1430 \pm 49 \mu \mathrm{g} / \mathrm{mL}$ ). Single volatile compounds, such as linalool, phenylethyl alcohol, citronellol, and $\alpha$-bisabolol, exhibited weak antiradical activities $\left(\mathrm{IC}_{50}\right.$ values of $\left.>10,000 \mu \mathrm{g} / \mathrm{mL}\right)$.

\section{Tyrosinase inhibitory activities}

Tyrosinase is a multifunctional copper-containing enzyme found in fungi, mammals, and plants [29]. Tyrosinase has two distinct enzyme activities, namely, monophenolase activity and diphenolase activity [30]. We conducted an initial study of the tyrosinase inhibitory activities of mushroom tyrosinase. As per this assay, RFCS showed strongly tyrosinase inhibitory activities with an $\mathrm{IC}_{50}$ value of $570 \pm 21 \mu \mathrm{g}$ / $\mathrm{mL}$ (Table 3). The volatile compounds, including linalool, phenylethyl alcohol, citronellol, and $\alpha$-bisabolol, also showed dose-dependent tyrosinase inhibitory effects with $\mathrm{IC}_{50}$ values of $730 \pm 44 \mu \mathrm{g} / \mathrm{mL}, \quad 315 \pm 13 \mu \mathrm{g} / \mathrm{mL}, 825 \pm$ $31 \mu \mathrm{g} / \mathrm{mL}$, and $635 \pm 22 \mu \mathrm{g} / \mathrm{mL}$, respectively. All the flavonoid compounds, namely, hyperoside, kaempferol-3-O-rutinosid, and even rutin were more potent than kojic acid (80 $\pm 17 \mu \mathrm{g} / \mathrm{mL}$ ), and they all had $\mathrm{IC}_{50}$ values bellow $1 \mu \mathrm{g} / \mathrm{mL}$.

Similar to the report by Solimine, the polyphenolenriched fraction of RODW, which contains flavonoid compounds, exhibits obvious tyrosinase inhibitory activity with an $\mathrm{IC}_{50}$ value of $0.41 \pm 0.01 \mu \mathrm{g} / \mathrm{mL}$ [6]. Meanwhile, the tyrosinase inhibitory effects of RFCS is stonger than RODW from Pingyin [13]. The flavonoid content contributes to the overall tyrosinase inhibitory effect of RODW.

\section{Antimicrobial activities}

The results of the antimicrobial activity studies of the different rose fractions, RFCS, and the standard antibiotics (tetracycline and hydrochloride) are presented in Table 4. F. nucleatum was most susceptible to RFCS and showed an MIC of $64 \mu \mathrm{g} / \mathrm{mL}$ and MBC of $250 \mu \mathrm{g} / \mathrm{mL}$. The MIC values for RFCS against both $P$. acnes and $S$. aureus were $125 \mu \mathrm{g} / \mathrm{mL}$. The MIC values against other bacteria were $250 \mu \mathrm{g} / \mathrm{mL}$. The MIC and MBC or MFC values of the nine components of RFCS were determined to identify the constituents responsible for the antimicrobial effects of RFCS. L. ivanovii and F. nucleatum were found to be the most susceptible to $\alpha$-bisabolol, and it showed MIC values of $8 \mu \mathrm{g} / \mathrm{mL}$ and MBC values of $32 \mu \mathrm{g} / \mathrm{mL}$ against these species (Table 4). After $\alpha$-bisabolol, phenylethyl alcohol showed the lowest MIC and MBC or MFC values among all the constituents of RFCS. Overall, the volatile constituents played a more important role than the flavonoid compounds in the antimicrobial activity of RFCS.

Previous investigations of the antimicrobial effects of the various fractions of rose have reported similar results $[8,28,31]$. The essential oil and various extracts of rose, including the aqueous extract, ethanol extract, chloroform extract, ethyl acetate fraction, and butanol fraction, exhibit broad-spectrum antimicrobial activities. With the exception of the ethyl acetate fraction, rose essential oil is comparatively more active against the tested bacteria [28]. The absolute and essential oils of rose contain high levels of polyphenols and phenylethyl alcohol, which result in outstanding antimicrobial properties [8]. Because 
Table $4 \mathrm{MIC}$ and MBC or MFC of RFCS and different monomers against pathogenic bacteria $(\mu \mathrm{g} / \mathrm{mL})$

\begin{tabular}{|c|c|c|c|c|c|c|c|c|c|c|c|c|c|c|}
\hline \multirow[t]{2}{*}{ Compound } & \multicolumn{2}{|c|}{ L. ivanovii } & \multicolumn{2}{|c|}{ S. enteritidis enteritidis } & \multicolumn{2}{|c|}{ S. aureus } & \multicolumn{2}{|c|}{ E. coli } & \multicolumn{2}{|c|}{ C. albicans } & \multicolumn{2}{|c|}{ P. acnes } & \multicolumn{2}{|c|}{ F. nucleatum } \\
\hline & MIC & $\mathrm{MBC}$ & MIC & $\mathrm{MBC}$ & MIC & $\mathrm{MBC}$ & MIC & $\mathrm{MBC}$ & $\mathrm{MIC}$ & MFC & $\mathrm{MIC}$ & $\mathrm{MBC}$ & $\mathrm{MIC}$ & $M B C$ \\
\hline RFCS & 500 & $>1000$ & 500 & $>1000$ & 125 & 1000 & 500 & 1000 & 1000 & $>1000$ & 125 & 500 & 64 & 250 \\
\hline Linalool & 500 & $>1000$ & 500 & $>1000$ & 250 & 1000 & 250 & 1000 & 250 & 1000 & 250 & 1000 & 250 & 1000 \\
\hline Phenylethyl alcohol & 250 & 500 & 125 & 500 & 125 & 250 & 250 & 1000 & 250 & 500 & 125 & 500 & 8 & 32 \\
\hline Citronellol & 250 & 500 & 250 & 1000 & 125 & 500 & 250 & 500 & 250 & 500 & 125 & 500 & 250 & 1000 \\
\hline a-bisabolol & 8 & 32 & 500 & $>1000$ & 250 & 1000 & 500 & 1000 & 1000 & $>1000$ & 125 & 500 & 8 & 32 \\
\hline Hyperoside & 250 & 500 & 250 & 500 & 250 & 1000 & 250 & 1000 & 250 & 1000 & 250 & 1000 & 250 & 500 \\
\hline Kaempferol-3-O-rutinosid & 500 & 1000 & 500 & $>1000$ & 250 & 1000 & 500 & $>1000$ & 250 & 1000 & 500 & 1000 & 500 & $>1000$ \\
\hline Rutin & 500 & 1000 & 125 & 500 & 250 & 500 & 250 & 1000 & 500 & 1000 & 125 & 250 & 62 & 500 \\
\hline Luteolin & 500 & 1000 & 250 & 1000 & 500 & $>1000$ & 250 & 1000 & 250 & 500 & 250 & 500 & 125 & 500 \\
\hline Miconazole Nitrate & - & - & - & - & - & - & - & 16 & 8 & - & - & - & - & - \\
\hline Hydrochloride tetracycline & $<0.1$ & $<0.1$ & 8 & 16 & 16 & 16 & 16 & - & - & 16 & 8 & 16 & 2 & 2 \\
\hline
\end{tabular}

Data are expressed as mean \pm standard deviation of triplicate samples

MIC minimum inhibitory concentration, MBC minimum bactericidal concentration, MFC minimum Fungicidal concentration, RFCS rose flower cell sap, $L$. ivanovii Listeria ivanovii, S. enteritidis subspecies enteritidis: Salmonella enteritidis enteritidis, S. aureus Staphylococcus aureus, E. coli Escherichia coli, C. albicans Candida albicans, P. acnes Propionibacterium acnes, F. nucleatum Fusobacterium nucleatum

the content of volatile oil in RODW is higher than RFCS, the antimicrobial effect of RODW better than RFCS [13]. The polyphenolic-enriched fraction from rugosa tea could inhibit Escherichia coli and Pseudomonas aeruginosa quorum sensing and biofilm formatiosignificancen [1]. The antimicrobial effects of some of the active ingredients of rose oil such as linalool, citronellol, and geraniol have been confirmed $[32,33]$. To date, the antimicrobial activity of RFCS of $R$. fenghua has not been evaluated. This result explicitly supports the fact that high contents of phenylethyl alcohol and other volatile components contribute to the antimicrobial activities of RFCS [34].

\section{Conclusions}

Our study demonstrated the strong antioxidant, antimicrobial, and tyrosinase inhibitory activities of RFCS. Due to the rose-like aroma of phenylethyl alcohol in combination with the tyrosinase inhibitory activities and antimicrobial effect against $S$. enteritidis subspecies enteritidis, C. albicans, and P. acnes, RFCS may be used as a natural skin-whitening and skin care additive in the cosmetics industry. Additionally, due to its antioxidant activities and antimicrobial effects against $L$. ivanovii, $S$. subspecies, E. coli, and S. aureus, RFCS can be used as a natural preservative and antimicrobial agent in the food and pharmaceutical industries.

\section{Abbreviations}

BHI: Brain heart infusion; CDC: Anaerobic blood agar base medium; ESI: Electrospray ionization; GAM broth: Actinomycete broth medium; MBC: Minimum bactericidal concentration; MFC: Minimum fungicidal concentration; MIC: Minimum inhibitory concentration; MS: Mass spectrometer; RFCS: Rosa rugosa Thunb. var. plena Regal flower cell sap; RODW: Rose oil distillation wastewater; ROS: Reactive oxygen species
Acknowledgments

Thank you to the Fragrant Rose Biological Technology Co., LTD in Pingyin for providing the RFCS.

\section{Funding}

This work was supported by the Ginseng Planting Resource Collection and Innovation (No. 20151FDA31290).

Availability of data and materials

The datasets used and/or analysed during the current study are available from the corresponding author on reasonable request.

\section{Authors' contributions}

GR, GZ and PX conceived the study. GR and GZ were responsible for data collection and data entry. PX and XS analyzed data and wrote the manuscript. All authors read and approved the final manuscript.

Ethics approval and consent to participate

This chapter does not contain any studies with human participants or animals performed by any of the authors and there is no informed consent involved.

Consent for publication

Not applicable.

\section{Competing interests}

The authors declare that they have no competing interests.

\section{Publisher's Note}

Springer Nature remains neutral with regard to jurisdictional claims in published maps and institutional affiliations.

\section{Author details}

${ }^{1}$ College of Pharmacy and Biological Engineering, Chengdu University, Chengdu 610000, People's Republic of China. ${ }^{2}$ Social Risk Prediction and Management, School of Public Health and Management, Weifang Medical University, No.7166 Baotong West Street Weicheng District, Weifang 261053, People's Republic of China. ${ }^{3}$ Key Laboratory of Coarse Cereal Processing, Ministry of Agriculture, No.2025 Chengluo Road, Longquanyi District, Chengdu 610106, People's Republic of China. ${ }^{4}$ Institute of Crop Sciences, Chinese Academy of Agricultural Sciences, No.80 XUEYUAN South Road, Handian District, Beijing 100081, People's Republic of China. 
Received: 9 July 2018 Accepted: 7 November 2018

Published online: 20 November 2018

\section{References}

1. Zhang JM, Rui X, Wang L, Guan Y, Sun XM, Dong MS. Polyphenolic extract from Rosa rugosa tea inhibits bacterial quorum sensing and biofilm formation. Food Control. 2014:42:125-31.

2. Tursun X, Zhao YX, Talat Z, Xin XL, Tursun A, Abdulla R, Akber AH. Antiinflammatory effect of Rosa rugosa flower extract in lipopolysaccharide -stimulated RAW264.7 macrophages. Biomol Ther. 2016;24:184-90.

3. Thao NP, Luyen BTT, Tai BH, Yang SY, Jo SH, Cuong NX, Nam NH, Kwon Yl, Minh CV, Kim YH. Rat intestinal sucrase inhibition of constituents from the roots of Rosa rugosa Thunb. Bioorg Med Chem Lett. 2014:24:1192-6.

4. Lee HJ, Ahn JW, Lee BJ, Moon SG, Seo Y. Antioxidant activity of Rosa rugosa. Ksbb J. 2004;19:67-71.

5. Kovacheva N, Rusanov K, Atanassov I. Industrial cultivation of oil bearing rose and rose oil production in Bulgaria during 21st century, directions and challenges. Biotechnol Biotec Eq. 2010;24:1793-8.

6. Solimine J, Garo E, Wedler J, Rusanov K, Fertig O, Hamburger M, Atanassov I, Butterweck $V$. Tyrosinase-inhibitory constituents from a polyphenol enriched fraction of rose oil distillation wastewater. Fitoterapia. 2016;108:13-9.

7. Callaway TR, Edrington TS, Anderson RC, Byrd JA, Nisbet DJ. Gastrointestinal microbial ecology and the safety of our food supply as related to salmonella. J Anim Sci. 2008:86:163-72.

8. Shohayeb M, Abdel-Hameed ESS, Bazaid SA, Maghrabi I. Antibacterial and antifungal activity of Rosa damascena MILL.Essential oil, different extracts of rose petals. Global J Pharmac. 2014:8:01-7.

9. Kim S, Lee S, Gwak K, Lee J, Choi I. Whitening effect and antioxidant activity of essential oils from Cryptomeria japonica. Planta Med. 2011;77:1301.

10. Baek SH, Nam IJ, Kwak HS, Kim KC, Lee SH. Cellular anti-melanogenic effects of a euryale ferox seed extract ethyl acetate fraction via the lysosomal degradation machinery. Int J Mol Sci. 2015;16:9217-35.

11. Roh JS, Han JY, Kim JH, Hwang JK. Inhibitory effects of active compounds isolated from safflower (Carthamus tinctorius L.) seeds for melanogenesis. Biol Pharm Bull. 2004:27:1976-8.

12. Takaki A, Yamamoto K. Control of oxidative stress in hepatocellular carcinoma: helpful or harmful? World J Hepatol. 2015:7:968-79.

13. Xue P, Sun XY, Zhang WY, Wang QC, Ren GX. Phytochemical constituents, antioxidant, antimicrobial, Tyrosinase inhibitory activities of RODW. Modern Food Sci Tech. 2017:33:105-10

14. Briehl MM. Oxygen in human health from life to death - an approach to teaching redox biology and signaling to graduate and medical students. Redox Bio. 2015:5:124-39.

15. Ellinsworth DC. Arsenic, reactive oxygen, and endothelial dysfunction. J Pharmacol Exp Ther. 2015;353:458-64

16. Balaguer A, Chisvert A, Salvador A. Environmentally friendly LC for the simultaneous determination of ascorbic acid and its derivatives in skinwhitening cosmetics. J Sep Sci. 2008;31:229-36.

17. Fawole OA, Makunga NP, Opara UL. Antibacterial, antioxidant and tyrosinase-inhibition activities of pomegranate fruit peel methanolic extract. BMC Complem Altern Med. 2012;12:1-11.

18. Park KM, Kwon KM, Lee SH. Evaluation of the antioxidant activities and tyrosinase inhibitory property from Mycelium Culture extracts. Evid-Based Compl Alt Med. 2015;2015:616298-304.

19. Thaipong K, Boonprakob U, Crosby K. Comparison of ABTS, DPPH, FRAP, and ORAC assays for estimating antioxidant activity from guava fruit extracts. J Food Compos Anal. 2006;19:669-75.

20. Xue P, Yao Y, Yang XS, Feng J, Ren GX. Improved antimicrobial effect of ginseng extract by heat transformation. J Gins Res. 2016:41:180-7.

21. Rusanov KE, Kovacheva NM, Atanassov II. Comparative gc/ms analysis of rose flower and distilled oil volatiles of the oil bearing rose. Biotechnol Biotec Eq. 2014;25:2210-6.

22. Koksal N, Saribas R, Kafkas E, Aslancan H, Sadighazadi S. Determination of volatile compounds of the first rose oil and the first rose water by hs-spme/ gc/ms techniques. Afr J Tradit Complem Alt Med. 2015;1212:145-50.

23. Mahboubifar M, Shahabipour S, Javidnia K. Evaluation of the valuable oxygenated components in iranian rose water. Intern Int J Chemtech Res. 2014;6:4782-8.

24. Lei G, Wang L, Liu X, Zhang A. Fast quantification of phenylethyl alcohol in rose water and chemical profiles of rose water and oil of and from Southeast China. J Liq Chromatogr Rela Tech. 2015;38:823-32.
25. Wong PY, Kitts DD. Studies on the dual antioxidant and antibacterial properties of parsley (petroselinum crispum) and cilantro (coriandrum sativum) extracts. Food Chem. 2006;97:505-15.

26. Li L, Ham H, Sung J, Kim Y, Lee H. Antioxidant activities of methanolic extracts from four different rose cultivars. J Food Nutr Res. 2014;2:69-73.

27. Netzel M, Strass G, Bitsch I, Konitz R, Christmann M, Bitsch R. Effect of grape processing on selected antioxidant phenolics in red wine. J Food Eng. 2003; 56:223-8.

28. Joo SS, Kim YB, Lee DI. Antimicrobial and antioxidant properties of secondary metabolites from white rose flower. Plant Pathol J. 2010;26:57-62.

29. Saanchez-Ferrer A, Rodríguez-López JN, García-Cánova F, García-Carmona F. Tyrosinase: a comprehensive review of its mechanism. Bioch Et Biophy Acta. 1995:1247:1-11.

30. Kim YJ, Uyama H. Tyrosinase inhibitors from natural and synthetic sources: structure, inhibition mechanism and perspective for the future. Cell Mol Life Sci. 2005;62:1707-23

31. Said BOS, Haddadi-Guemghar H, Boulekbache-Makhlouf L, Rigou P, Remini $\mathrm{H}$, Adjaoud A. Essential oils composition, antibacterial and antioxidant activities of hydrodistillated extract of eucalyptus globulus fruits. Ind Crop Prod. 2016;89:167-75

32. Aridogan BC, Baydar H, Kaya S, Demirci M, Mumcum E. Antimicrobial activity and chemical composition of some essential oils. Arch Pharml Res. 2002;25:860-4

33. Gochev V, Wlcek K, Buchbauer G, Stoyanova A, Dobreva A, Schmidt E, Jirovetz L. Comparative evaluation of antimicrobial activity and composition of rose oils from various geographic origins, in particular Bulgarian rose oil. Nat Prod Commun. 2008;3:1063-8.

34. Etschmann MMW, Bluemke W, Sell D, Schrader J. Biotechnological production of 2-phenylethanol. Appl Microbiol Biot. 2002;59:1-8.

\section{Ready to submit your research? Choose BMC and benefit from:}

- fast, convenient online submission

- thorough peer review by experienced researchers in your field

- rapid publication on acceptance

- support for research data, including large and complex data types

- gold Open Access which fosters wider collaboration and increased citations

- maximum visibility for your research: over $100 \mathrm{M}$ website views per year

At $\mathrm{BMC}$, research is always in progress.

Learn more biomedcentral.com/submissions 